\title{
Analysing the Communication Process Between Middle and top Managers Through the Concept of 'Ba'
}

\author{
Jarrah Al-Mansour ${ }^{1}$ and Demola Obembe ${ }^{2}$ \\ ${ }^{1}$ Arab Open University, AOU Business School, Kuwait \\ ${ }^{2}$ De Montfort University, Leicester Castle Business School, UK \\ jarrah@aou.edu.kw \\ dobembe@dmu.ac.uk
}

\begin{abstract}
In the last few decades the relevance of knowledge management to organizations has become increasingly apparent. However, there are varying levels of emphasis on researching different aspects of this multidimensional construct. One such dimension is knowledge sharing, which is extensively researched from an impact perspective but with limited research on understand dynamic interactions of actors. In this research, we aim to explore factors influencing knowledge sharing among top and middle managers during the strategy communication process. We further draw on the concept of 'ba' as an alternative interpretive tool for understanding managerial interaction dynamics. Adopting a qualitative approach, 32 semi-structured interviews were conducted across a single case Kuwaiti public sector ministry and collated data presented as a thematic narrative to capture managerial perspectives. The findings indicate that organizations benefit more from aligning heterogenous groups within common collective spaces, and that social spaces or contexts are critically important for sharing knowledge pertinent to successful execution of strategies. Furthermore, the propensity to share knowledge was found to be dependent on the tribal affiliations of individual actors, and knowledge sharing dispositions was impacted by prejudices and social stereotypes. The research proposes practical considerations for organization management to foster knowledge exchange among the workforce.
\end{abstract}

Keywords: 'ba', knowledge sharing, strategy communication process, top and middle managers, public sector

\section{Introduction}

Organizational knowledge often assumes a variety of forms, which not only contribute to its complexity but make its communication and management challenging (Blackler, 1995, Obembe, Al Mansour and Kolade, 2020). As such knowledge is created and sustained through human involvement, there is a need to understand the social practices of individuals involved in the development process. Nonaka and Takeuchi first proposed the SECl model of organization knowledge creation in 1995. However, in recognition of the limitations of this model, Nonaka and colleagues introduced the concept of 'ba', to capture a broader dynamic view of knowledge creation and provide a conceptual understanding that supports creation and utilization of such knowledge (Nonaka and Konno, 1998; Nonaka, Von Krogh and Voelpel, ., 2006; Nonaka and Toyama, 2015). Thus, the development of 'ba' promotes an understanding of knowledge creation and equally, information delivery between individuals within organizational boundaries.

The knowledge management literature, particularly in the strategy discipline, has taken different theoretical perspectives. These include for instance, the resource-based view which represents organizations and their respective strategies as sets of collective resources that can be exploited to achieve sustainable competitive advantage (Jarzabkowski et al., 2016; Bromiley and Rau, 2016). The dynamic capability view on the other hand is underpinned by institutional routines, managerial perspectives, and the ability for institutions to integrate and develop internal competences (Rashidirad et al., 2017; Liu et al., 2018). We then have the knowledgebased view which further considers knowledge as the most vital asset through which organizations develop their strategies and acquire unique strategic positioning (Donate and de Pablo, 2015; Dong et al., 2017).

These approaches often erroneously position Knowledge management and exchange as clearly comprehensible tangible elements in strategy process. Hence the need for, alternative views to consider the development of social constructs for interpreting individual social behaviour. One such is institutional theory, which provides deeper insight into social structures within organizations (Tolbert and Zucker, 1999; Peters, 2019). Similarly, social practice theory (Giddens, 1984; Bourdieu, 1990), helps us to understand the dynamic interaction activities of social actors within knowledge sharing and strategy communication processes. However, even with such alternative views, there is still limited explanation for how knowledge is created and shared through social interactions among sets of individuals. It is in this regard that we propose the use of the 
concept of 'ba' to explain how knowledge and information are communicated between individuals in order to ensure desirable strategy outcomes.

Based on the premise that human interactions are embedded within their social constructs and practice, we provide insight on how knowledge is managed, communicated, and transferred among two managerial groups; top and middle managers, in a public sector context (Titi Amayah, 2013; Henttonen, Kianto and Rialto, 2016; Jørgensen et al., 2020). We apply the concept of 'ba' in the context of strategic management to understand its application in interpreting individual interactions - particularly as it relates to communications between various strategy processes (formulation, implementation, and control). In so doing, we engage the concept of 'ba' to address the research question; what factors influence knowledge sharing during communication of strategy processes among top and middle managers? Furthermore, in addressing this research question, through the application of 'ba', we contribute to the knowledge management literature by extending the applicability of 'ba' beyond knowledge creation to knowledge sharing.

\section{Theoretical background}

\subsection{Knowledge creation and 'Ba'}

Nonaka and Takeuchi's (1995) authorship of The Knowledge-Creating Company marked a watershed moment in knowledge management studies. Since then, there has been a considerable expansion in the knowledge management literature, including parallel interests in its interrelated concepts; knowledge generation, representation, accessibility, and transfer (Lahti and Beyerlein, 2000). There have also been a proliferation of research into various dimensions of knowledge, including knowledge types (Forés and Camisón, 2016), knowledge creation process (Nonaka and Toyama, 2015), knowledge-based theory (Nonaka, Von Krogh and Voelpel, 2006; Low and Ho, 2016; Nikolaou, 2019); knowledge transfer (Manfredi Latilla, 2018), knowledge sharing (Obembe, 2010; 2013; Ahmad and Karim, 2019), organizational epistemology (Tsoukas, 2005), knowledge acquisition (Yli-Renko, Autio and Sapienza, 2001), knowledge taxonomies (Saeed and Sattar Chaudhry, 2002), and enabling contexts (Choo and Alvarenga Neto, 2010; Fletcher, 2014). Due to the significant progresses in the field, knowledge creation is often positioned in the literature as a core dynamic asset of organizations, which allows internal social actors to interact and exchange relevant knowledge.

Organizational knowledge is thus viewed as an asset that is embedded in interactions of individuals and constructed through social practice involving individual actors (Von Krogh, Nonaka and Ichijo, 1997, 1997; von Krogh, 1998; Von Krogh, Nonaka, and Rechsteiner, 2012). Knowledge creation is viewed within the organizational context as the process of making knowledge created by individuals available and linking it to the main organizational knowledge structure (Nonaka, Von Krogh and Voelpel, 2006). This organizational knowledge process is also part of the wider concept of knowledge management (KM), characterized by its complexity and ambiguity. This complexity is thus due to the intricacy of individuals and their interactive relations, which serve as the main source of knowledge creation and knowledge sharing.

The introduction of 'ba' to the knowledge creation model is particularly significant as it provides a context for social praxis. The word itself roughly equates to 'place' and has been defined as a shared context in motion, i.e., emergent contexts where knowledge is shared, created, and utilized (Nonaka and Toyama, 2003). The concept can also be construed in terms of shared physical or mental spaces where relationships develop. In this regard, we opine that it is this temporal and spatial attribute of 'ba' that enables the shared context to continuously evolve and facilitate participant interaction (Nonaka, Toyama and Konno, 2001).

Nonaka and Konno (1998) identified four types of 'ba'; originating 'ba', interacting or dialoguing 'ba', cyber or systematizing 'ba', and exercising 'ba'. Each of these correspond to the four stages of the SECl model of knowledge creation and provide support platforms for the knowledge spiral process. Nonaka and Toyama (2003) further argue that dialectic thinking allows for the transcendence and synthesis of seeming contradictions to create a 'good ba' and energy, for knowledge conversion and movement along the knowledge spiral. However, the 'ba' thus created is itself still dependent on participants having multiviewpoints to foster the shared context.

Although the introduction of 'ba' to the knowledge management literature was geared towards providing a basis for the articulation of the knowledge conversion process as social praxis, according to Nonaka and Toyama (2003) it can either hinder or stimulate knowledge creative activities. In a similar vein, in considering 
the originating 'ba' and the interacting 'ba', which both lend themselves to social interaction, we posit that social spaces may equally facilitate or hinder communication of knowledge among individuals. Indeed, Nonaka, Von Krogh and Voelpel, (2006) noted the possibility for 'ba' to constitute a hindrance to creating new knowledge as both originating and interacting 'bas' may foster groupthink as well as limit the participation of outsiders within the collective spaces.

\subsection{Knowledge sharing within the strategy communication process}

Knowledge is considered the most valuable intangible asset for social actors and invariably the most valuable strategic organizational resource (Wang and Noe, 2010). Unlike other fixed resources, knowledge is produced and reproduced through its use and application (Dodgson, 1993). Knowledge sharing can be construed as a social communication process; the exchange of information, skills, and ideas between social actors within a certain context, With the organization context representing boundaries within which the process occurs (Cooper et al., 2019).

Since knowledge sharing enhances organizational effectiveness, employee performance, and creativity (Andrews and Delahaye, 2000; Inkinen, Kianto and Vanhala, 2015; Jamshed and Majeed, 2018), it is required in all strategy processes, including formulation, implementation, and control. The engagement of various social actors in the strategy process further provides an opportunity for shared understanding (Wooldridge and Floyd, 1990). Choo and Alvarenga Neto (2010) similarly identified strategy/structure as one of four groups of conditions that enable knowledge creation. The others being; social/behavioural, cognitive/epistemic, and information systems/management. In essence, shared knowledge between internal social actors can enhance strategy communication, regardless of the organization size (Bennett, 2001). Furthermore, in strategy-related research, strategy-as-practice researchers have undertaken extensive research into strategic management and social practice. For instance, both Whittington (2006) and Jarzabkowski and Spee (2009) offer justifiable explanations for the interrelations between practitioners, their practices and interactions, and the praxis of their organizations. We thus identify an existent nexus between knowledge sharing and social practices in strategy communication and further view 'ba' as a useful interpretive tool for making sense of this vital link. In this sense, Bennett (2001) notes that 'ba' is not limited by the size of an organization, but rather depends on managerial attitudes, traits, and dispositions. These attributes may prove essential to boost knowledge sharing propensities between various managerial levels during the strategy communication process.

\subsection{Top and middle manager knowledge sharing in the strategy communication process}

There is a general belief that strategy-related practices are solely directed by top management teams, seen to be the ideal strategy practitioners (Jarzabkowski, 2005; Raes et al., 2011; Ouakouak, Ouedraogo and Mbengue, 2014). However, many researchers have highlighted the importance of looking at other managerial levels within the strategy communication process (Ahearne, Lam and Kraus, - 2014; Gatenby et al., 2015; Obembe, Al Mansour and Kolade, 2020). Middle managers play a critical strategic role during strategy formulation and implementation processes (Huy, 2001; Mantere, 2008; Rouleau and Balogun, 2011; Martin-Rios, 2016).

Within normal organizational contexts, a clear knowledge sharing process may not always be apparent due to differences in individuals' approaches to social interaction. Several researchers have stressed the importance of aligning managerial groups during various strategy processes (Wooldridge, Schmid and Floyd, 2008; Raes et al., 2011; Glaser, Fourné and Elfring, 2015). Adamides (2015) highlights the importance of engaging functional stakeholders in the communication process itself as it positively influences the alignment of the overall organizational strategy. Equally, Al Saifi, Dillon and McQueen, (2016) articulated the critical role of top and middle managers in supporting knowledge sharing by, for example, encouraging manager engagement in the decision-making loop, building teams, aligning knowledge into practice, and encouraging formal and informal communications.

Although strategy communication research supports the importance of alignment between top and middle managers in sharing knowledge, scant attention is given to the dynamic interaction between the managerial groups, which may lead to misunderstandings and delays in executing strategies (Raes et al., 2011). 


\section{Methodology}

\subsection{Sampling and data collection}

This research is geared towards understanding how strategic knowledge is communicated between top and middle managers. As such, we adopted a qualitative approach to explore the perceptions, beliefs, stories, experiences, and practices of individuals within the managerial levels. Our data was collected as a single case study from a public sector organization in Kuwait (Yin, 2014).

Although the Kuwaiti public sector is context is vast in nature, our choice of the particular case organization was premised on two factors. First, was the fact that the case organization is one of the largest and most active ministries in Kuwait. Secondly, the selected case organization has a significant number of internal interacting departments and units, which makes it conducive for exploring how strategic knowledge is communicated across managerial levels.

A total of 32 semi-structured interviews were conducted and respondents were identified through a combination of purposive and snowball sampling techniques (Patton, 2015). The interview protocol was designed and refined prior to engaging in the actual fieldwork activities to assure clarity and all ethics protocols were duly observed. Table 1 below reports the profile of the interviewees.

Table 1: Interviewee profile

\begin{tabular}{|c|c|c|c|c|c|c|}
\hline $\mathrm{S} / \mathrm{N}$ & ID & Managerial Level & Gender & $\begin{array}{l}\text { Managerial } \\
\text { Role }\end{array}$ & Job Function & $\begin{array}{l}\text { Minimum } \\
\text { Experience }\end{array}$ \\
\hline 1 & $\begin{array}{l}\text { I-1- } \\
\text { MM }\end{array}$ & Middle Management & Male & $\begin{array}{c}\text { Departmental } \\
\text { Head }\end{array}$ & Project Supervisor & 8 Years \\
\hline 2 & $\begin{array}{l}\mathrm{I}-2- \\
\mathrm{MM}\end{array}$ & Middle Management & $\begin{array}{c}\text { Femal } \\
\mathrm{e}\end{array}$ & $\begin{array}{c}\text { Departmental } \\
\text { Head }\end{array}$ & Supervisor in Supply Projects & 8 Years \\
\hline 3 & $\begin{array}{l}\text { I-3- } \\
\text { MM }\end{array}$ & Middle Management & $\begin{array}{c}\text { Femal } \\
\mathrm{e}\end{array}$ & $\begin{array}{c}\text { Departmental } \\
\text { Head }\end{array}$ & Technical Support Team Leader & 8 Years \\
\hline 4 & $\begin{array}{l}\text { I-4- } \\
\text { TM-R }\end{array}$ & $\begin{array}{l}\text { Top Management } \\
\text { (Retired) }\end{array}$ & Male & Division Head & $\begin{array}{c}\text { Manager in Control Unit and } \\
\text { Surveillance }\end{array}$ & 10 Years \\
\hline 5 & $\begin{array}{l}\mathrm{I}-5- \\
\mathrm{TM}\end{array}$ & Top Management & Male & Division Head & Manager in Maintenance & 10 Years \\
\hline 6 & $\begin{array}{l}\text { I-6- } \\
\text { MM }\end{array}$ & Middle Management & Male & $\begin{array}{l}\text { Departmental } \\
\text { Head }\end{array}$ & $\begin{array}{c}\text { Supervisor in Administrative } \\
\text { Affairs }\end{array}$ & 8 Years \\
\hline 7 & $\begin{array}{l}\mathrm{I}-7- \\
\mathrm{TM}\end{array}$ & Top Management & $\begin{array}{c}\text { Femal } \\
\mathrm{e}\end{array}$ & Unit Head & $\begin{array}{c}\text { Manager in Training and } \\
\text { Research }\end{array}$ & 10 Years \\
\hline 8 & $\begin{array}{l}\text { I-8- } \\
\text { MM }\end{array}$ & Middle Management & Male & $\begin{array}{c}\text { Departmental } \\
\text { Head }\end{array}$ & Assistant Supervisor in Media & 8 Years \\
\hline 9 & $\begin{array}{l}\text { I-9- } \\
\text { MM }\end{array}$ & Middle Management & Male & $\begin{array}{c}\text { Departmental } \\
\text { Head }\end{array}$ & Networks Team Leader & 8 Years \\
\hline 10 & $\begin{array}{l}\mathrm{I}-10- \\
\mathrm{MM}\end{array}$ & Middle Management & Male & $\begin{array}{l}\text { Departmental } \\
\text { Head }\end{array}$ & Consumer Affairs Consultant & 8 Years \\
\hline 11 & $\begin{array}{l}\text { I-11- } \\
\text { TM }\end{array}$ & Top Management & Male & Division Head & $\begin{array}{c}\text { Manager in Projects and } \\
\text { Networks }\end{array}$ & 10 Years \\
\hline 12 & $\begin{array}{l}\mathrm{I}-12- \\
\mathrm{MM}\end{array}$ & Middle Management & $\begin{array}{c}\text { Femal } \\
\mathrm{e}\end{array}$ & $\begin{array}{l}\text { Departmental } \\
\text { Head }\end{array}$ & $\begin{array}{c}\text { Assistant Supervisor in } \\
\text { Maintenance }\end{array}$ & 8 years \\
\hline 13 & $\begin{array}{l}\text { I-13- } \\
\text { MM }\end{array}$ & Middle Management & Male & $\begin{array}{l}\text { Departmental } \\
\text { Head }\end{array}$ & Quality Assurance Team Leader & 8 years \\
\hline 14 & $\begin{array}{l}\text { I-14- } \\
\text { MM }\end{array}$ & Middle Management & Male & $\begin{array}{l}\text { Departmental } \\
\text { Head }\end{array}$ & $\begin{array}{c}\text { Consultant in Administrative } \\
\text { Affairs }\end{array}$ & 8 years \\
\hline 15 & $\begin{array}{l}\mathrm{I}-15- \\
\mathrm{MM}\end{array}$ & Middle Management & Male & $\begin{array}{l}\text { Departmental } \\
\text { Head }\end{array}$ & $\begin{array}{c}\text { Assistant Team leader in Legal } \\
\text { Affairs }\end{array}$ & 8 years \\
\hline 16 & $\begin{array}{l}\mathrm{I}-16- \\
\mathrm{MM}\end{array}$ & Middle Management & Male & $\begin{array}{l}\text { Departmental } \\
\text { Head }\end{array}$ & $\begin{array}{c}\text { Supervisor in Operation and } \\
\text { Maintenance }\end{array}$ & 8 years \\
\hline 17 & $\begin{array}{l}\mathrm{I}-17- \\
\mathrm{MM}\end{array}$ & Middle Management & Male & $\begin{array}{l}\text { Departmental } \\
\text { Head }\end{array}$ & Supervisor in Technical Services & 8 years \\
\hline 18 & $\begin{array}{c}\text { I-18- } \\
\text { TM }\end{array}$ & Top Management & Male & Division Head & $\begin{array}{c}\text { Manager in Networks } \\
\text { Maintenance }\end{array}$ & 10 years \\
\hline 19 & $\begin{array}{l}\text { I-19- } \\
\text { MM }\end{array}$ & Middle Management & Male & $\begin{array}{c}\text { Departmental } \\
\text { Head }\end{array}$ & Supervisor in Technical Control & 8 years \\
\hline
\end{tabular}




\begin{tabular}{|c|c|c|c|c|c|c|}
\hline $\mathrm{S} / \mathrm{N}$ & ID & Managerial Level & Gender & $\begin{array}{l}\text { Managerial } \\
\text { Role }\end{array}$ & Job Function & $\begin{array}{l}\text { Minimum } \\
\text { Experience }\end{array}$ \\
\hline 20 & $\begin{array}{l}\mathrm{I}-20- \\
\mathrm{MM}\end{array}$ & Middle Management & Male & $\begin{array}{l}\text { Departmental } \\
\text { Head }\end{array}$ & Production Supervisor & 8 years \\
\hline 21 & $\begin{array}{l}\mathrm{I}-21- \\
\mathrm{TM}\end{array}$ & Top Management & Male & Division Head & $\begin{array}{c}\text { Manager in Bids and Internal } \\
\text { Affairs }\end{array}$ & 10 years \\
\hline 22 & $\begin{array}{l}\mathrm{I}-22- \\
\mathrm{MM}\end{array}$ & Middle Management & Male & $\begin{array}{l}\text { Departmental } \\
\text { Head }\end{array}$ & Employment Team Leader & 8 years \\
\hline 23 & $\begin{array}{l}\text { I-23- } \\
\text { TM }\end{array}$ & Top Management & Male & Division Head & Manager in Project Design & 10 years \\
\hline 24 & $\begin{array}{l}\text { I-24- } \\
\text { TM }\end{array}$ & Top Management & Male & Division Head & Manager in Financial Affairs & 10 years \\
\hline 25 & $\begin{array}{l}\text { I-25- } \\
\text { TM }\end{array}$ & Top Management & Male & Division Head & $\begin{array}{c}\text { Manager in Planning and Follow- } \\
\text { Up }\end{array}$ & 10 years \\
\hline 26 & $\begin{array}{l}\mathrm{I}-26- \\
\mathrm{MM}\end{array}$ & Middle Management & Male & $\begin{array}{l}\text { Departmental } \\
\text { Head }\end{array}$ & $\begin{array}{c}\text { Assistant Team Leader in Internal } \\
\text { Quality Assurance }\end{array}$ & 8 years \\
\hline 27 & $\begin{array}{l}\text { I-27- } \\
\text { TM-R }\end{array}$ & $\begin{array}{l}\text { Top Management } \\
\text { (Retired) }\end{array}$ & Male & Division Head & $\begin{array}{l}\text { Manager in Training and } \\
\text { Development }\end{array}$ & 10 years \\
\hline 28 & $\begin{array}{l}\text { I-28- } \\
\text { TM }\end{array}$ & Top Management & Male & Unit Head & Manager in Human Resources & 10 years \\
\hline 29 & $\begin{array}{l}\text { I-29- } \\
\text { TM }\end{array}$ & Top Management & $\begin{array}{c}\text { Femal } \\
\mathrm{e}\end{array}$ & Unit Head & $\begin{array}{c}\text { Department } \\
\text { Manager in Emergency Planning }\end{array}$ & 10 years \\
\hline 30 & $\begin{array}{l}\mathrm{I}-30- \\
\mathrm{MM}\end{array}$ & Middle Management & Femal & $\begin{array}{l}\text { Departmental } \\
\text { Head }\end{array}$ & Team Leader in Project Design & 8 years \\
\hline 31 & $\begin{array}{l}\text { I-31- } \\
\text { MM }\end{array}$ & Middle Management & e & Departmental & Assistant Manager for Archiving & 8 years \\
\hline 32 & $\begin{array}{l}\mathrm{I}-32- \\
\mathrm{MM}\end{array}$ & Middle Management & $\begin{array}{l}\text { Male } \\
\text { Femal } \\
\text { e }\end{array}$ & $\begin{array}{c}\text { Head } \\
\text { Departmental } \\
\text { Head }\end{array}$ & Team Leader in Directory & 8 years \\
\hline
\end{tabular}

\subsection{Data coding and analysis}

Upon finalizing the interviews, we manually analysed the collected data. Although manual coding can be time-consuming, we found it beneficial for the data analysis process as it allows researchers to be more conversant with the coded data (Chenail, 2012; Grbich, 2013). We adopted a thematic analysis approach, which is widely utilized in qualitative research and allows for researchers to compare theory and practice in parallel (Braun et al., 2019). First, open codes were assigned to each interview question and further broken down into sub-codes to create a sense of meaning to the raw data.

All the interviews were transcribed by one of the authors yielding 92 pages of transcribed data and 61 potential sub-themes. Common terms used by respondents were aggregated to form meaningful categories (see Table 2 below).

Table 2: Theme and code commonalities across the interviews

\begin{tabular}{|c|c|c|c|c|c|}
\hline Serial & Theme & Relative Codes & Respondents & Similar Words & Interviews \\
\hline 1 & $\begin{array}{l}\text { Dispositions } \\
\text { of top } \\
\text { management }\end{array}$ & $\begin{array}{l}\text { Losing power } \\
\text { Legitimacy }\end{array}$ & 27 & $\begin{array}{l}\text { Hidden information, no clear rules, } \\
\text { various opinions, deny promises, } \\
\text { avoid rotation, changes in priorities, } \\
\text { culture conflict, delegation issues, } \\
\text { personal act, mentality }\end{array}$ & 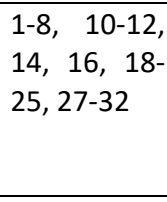 \\
\hline 2 & $\begin{array}{l}\text { Functionality } \\
\text { of middle } \\
\text { managers }\end{array}$ & $\begin{array}{l}\text { Protection } \\
\text { Lobbying } \\
\text { Tribes }\end{array}$ & 28 & $\begin{array}{l}\text { Social connection, collective } \\
\text { community, line of command, } \\
\text { protection, definition of authority, } \\
\text { code of conduct, grouping, } \\
\text { procedure and process, networks, } \\
\text { nepotism }\end{array}$ & $\begin{array}{l}2-24, \quad 26, \\
28-32\end{array}$ \\
\hline
\end{tabular}




\begin{tabular}{|c|c|c|c|c|}
\hline 3 & $\begin{array}{l}\text { Intersective } \\
\text { impediment } \\
\text { of knowledge } \\
\text { sharing }\end{array}$ & $\begin{array}{l}\text { Togetherness } \\
\text { Consensus }\end{array}$ & 31 & $\begin{array}{l}\text { Shared understanding, connection, 1-17, 19-32 } \\
\text { formal and informal routes, } \\
\text { communication disruption, } \\
\text { individual bias, teamwork spirit, } \\
\text { collectivism ethos }\end{array}$ \\
\hline
\end{tabular}

The coding process involved reviewing each transcript and identifying codes and themes that potentially offer insights to the proposed research aim. We controlled for data reliability by following a respondent validation technique in which we referred back to each respondent after transcribing the relevant interviews. Upon completing the manual analysis, we linked the codes that have clear connections to each other. For instance, "social ties" were linked to "lobbying" and further linked to "tribes". Figure 1 below, represents the final thematic map and code aggregation. Upon finalizing the data reduction process, three main themes were identified and reported as a narrative: dispositions of top management, functionality of middle manager, and interceptive impediment of knowledge sharing.

1st Order Concepts

2nd Order Themes

Aggregate

Dimensions

- Our position is our own power

- Delegation is not necessarily

- We act according to legitimate practice

- Who decides what is right and what is not?

- We believe it is a doctorial style

- Everyone is protected by others, this is the truth

- Yes, we do form groups for our own agenda

- Who said lobbying is not good for the workplace?

- Don't forget that we have strong culture

- Our society is a tribal and collective one

- We conflict all the time

- Regrettably, we are two separate groups

- We do not have a shared understanding of things

- Many issues need everyone's agreement

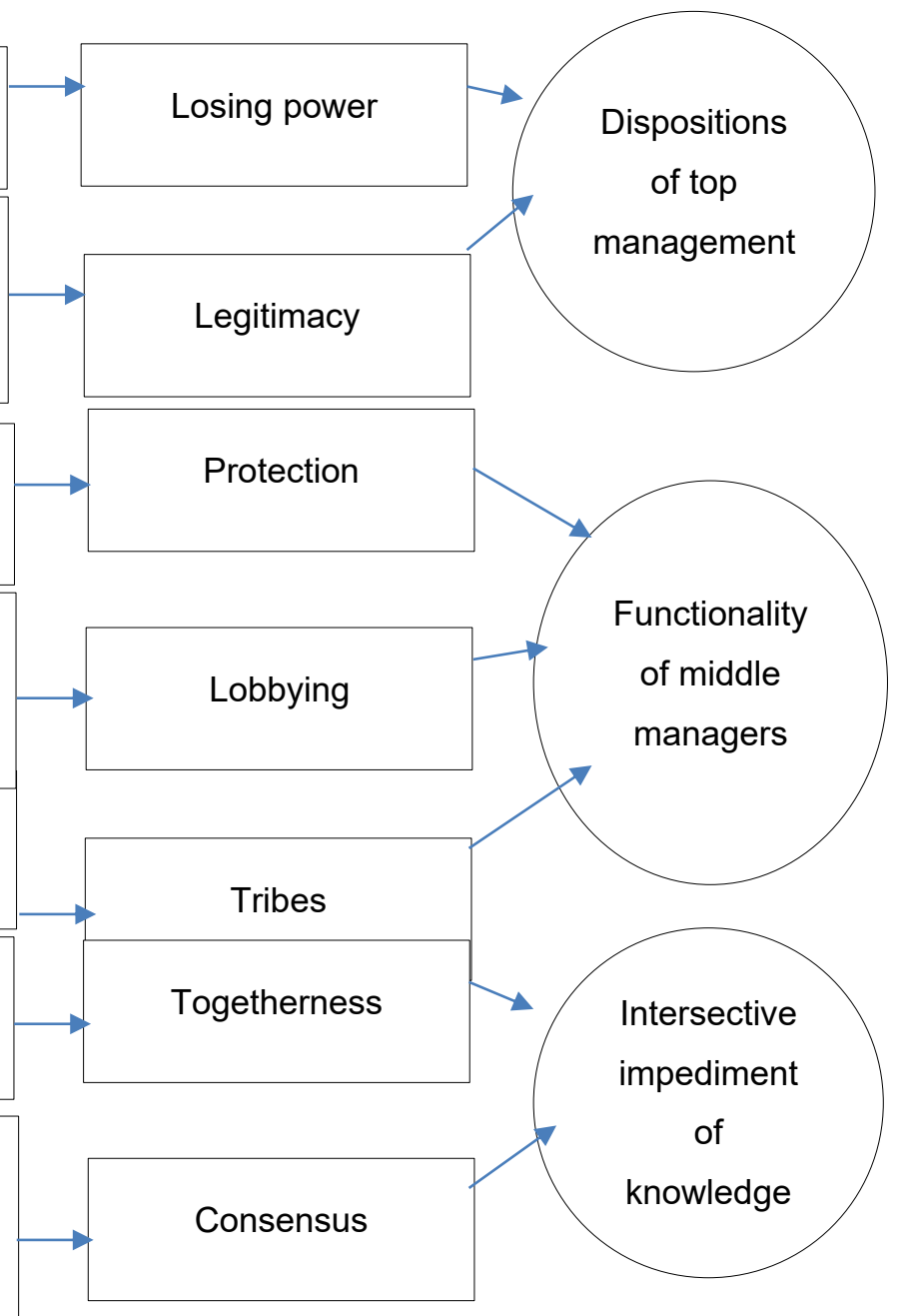

Figure 1: Final thematic map and code aggregation

(Source: Adapted from Corley and Gioia, 2004)

\section{Empirical data and findings}

The research findings indicate that whilst certain aspects of knowledge sharing may be considered as routine, in reality the process often proves significantly challenging when exchange of such knowledge involves interactions between individuals. This is because human social practice is complicated, and determining the 
nature of this complicity is what is interesting. Furthermore, human cognition is influenced by the nature of social practice within the organizational context. Due to the complexity of human cognition, it was difficult for both top and middle management to create a shared understanding and, thus, a clear space to freely share each other's knowledge. This in turn negatively contributed to the accomplishment of many strategic objectives within the various stages of the strategy process. The communication between the two managerial groups was also found to be regulated by their social interaction and the consequent influence of social ties.

In contrast to middle managers, top managers were disinclined to share information, strategies, or other skills and experiences. It was also interesting to note that not sharing information could provide certain security for top managers in the sense of retaining their position and associated power. This view was shared by 27 of the 32 interviewees, and is further exemplified by the following quotes:

We enjoy full authority as we act as top managers... sharing a lot of information might not benefit us in the long run! Right?! (I-29-TM)

From my experience, I think line managers enjoy not sharing all the details as this might let them feel devalued and threaten them along the way! (I-1-MM)

Furthermore, the fear of being replaced appears to be a reason for distrust and disconcert among the managers. This view is represented in the following quote:

One of the main reasons why they behave in such manner is that they think from inside that we may harm them one day and jump into their chairs! (I-14-MM)

In the job, I trust no-one, I only act according to my own feelings... you never know who your enemy might be! (I-18-TM)

I think that we should treat everyone here as a colleague, not as a friend or a family member... you cannot be open to everyone, don't you think?! (I-21-TM)

It was interesting to note that not openly sharing knowledge with others in the organization for lengthy periods might provide legitimacy for such practice. It may however be difficult to change this attitude without top leadership intervention:

When I remind my division manager about his responsibility to provide everything he knows to aid me supervise the various projects I am assigned to, he keeps saying 'no' and 'go and complain if you think that this is your right'! (I-2-MM)

Similar views were expressed by the top managers, as exemplified in the comment below:

We are not entitled to give everything we know to others... we act legally, and our practice is legitimate by work principles! (I-7-TM)

The top management sense of entitlement to retain knowledge appears further facilitated by a clear separation in operational and mental space among the two managerial groups:

If top managers think they have their own connections which protect them from accountability, we do also have even stronger connections to back us up! (I-3-MM)

Top managers should not forget that we are a valuable asset to them and to this ministry, if we do not exist, they do not exist, if they think they are immune from serious issues, we also have our own immune system! (I-6-MM)

The findings also indicate that social connections arising from familial relationships and cultural spaces may be integral to knowledge sharing among the managers as expressed in the following comments:

Our culture is a collective one... we do work in groups and we form lobbies for the benefit of individuals... this is obvious to everyone! (I-28-TM)

I openly share information with my relatives or those who belongs to my last family name... I also share the same information with those whom l've known for years and years... other than that I consider myself preservative! (I-9-MM) 
It is much easier for me to get the required information from someone who is connected with me by the blood or share the same family title!... truth cannot be denied. (I-29-TM)

The social connections and social practice of both top and middle managers within the ministry helped to understand the intersective impediment of KS as the third theme of this research. This was the most common theme in the dataset as it was addressed in 31 of 32 interviews conducted. The social connection node was anticipated given the Kuwaiti culture. Kuwait is considered a collective society bounded by strong ties between societal members; families, neighbours, and friends. These strong social ties play a critical role in building trust, mutual acceptance, and creating spaces for sharing knowledge. It is noteworthy that both top and middle managers acknowledge the absence of appropriate interactive spaces for socializing:

We need to feel for each other for the benefit of work, we need to be colleagues rather than enemies

of one another... I think this kind of spirit is missing somewhere! (I-3-MM)

We need to spend more time together, doing inside and outside social activities to know each other closely... but this should be in a way to keep an acceptable distance between us! (I-23-TM)

The latter response however seems to stress the importance of keeping certain spaces between the two management levels to avoid undesired future consequences. It can also be inferred that both teams act personally and rarely sat with each other and shared knowledge openly. Such disconnections lead to lack of information consensus between actors, as exemplifies in the following comments:

How can we reach a common understanding if we do not get together, trust each other, speak loudly and support one another!?" (I-25-TM)

I always get direct instructions from my manager to implement certain projects, but I really do not understand the single details which are more needed than just go and do! (I-32-MM)

Such views highlight the importance of forming a shared understanding or "consensus" between the management levels. Reaching a common understanding makes the work process smoother and allows more tasks to be accomplished.

\section{Discussion of findings}

In the extant knowledge management literature, there is still limited research on the facilitating contexts for social and behavioural influences, particularly among managerial groups. Although responses varied between the managerial groups, the findings suggest that public sector organizations will benefit from aligning heterogenous groups within common collective spaces in order to better facilitate knowledge sharing.

Our findings further outline the importance of context or social space in sharing knowledge relevant to executing organization strategies. This is evident from the observation that communication process tended to be largely associated with the tribal backgrounds and family affiliations of concerned parties. Furthermore, there were indications that individuals are more inclined to share knowledge where an enabling group environment exists rather than at individual levels. This is in line with the notion that where a team 'ba' exists, the self becomes part of the collective (Nonaka and Konno, 1998). In this regard, the greater the possibility of establishing a common space of interaction, the more inclined individuals inhabiting the space will share their knowledge.

We equally observed that communications between top and middle managers appeared to be affected by prejudices, social stereotypes, and social connections, which were likely to influence knowledge sharing tendencies and quality. The willingness of both managerial groups to share knowledge appeared to be further predicated on their expectations of equal treatment. This supports existing research that individual tendency to share knowledge in organizations is predetermined by the prevalence of conducive contexts and experiences (Obembe, 2013).

Surprisingly the cultural context was a major barrier to communicating knowledge required for strategy implementation. Although the existing culture was recognized as being collective, this was not suitably convincing to foster knowledge sharing between the two managerial levels. Indeed, normative personal interests acted as both enablers and impediment to knowledge sharing when respondents were required to 
communicate on strategy-related matters. The normative personal expectations thus present as a doubleedged sword within the organizational context. This is contrary to the findings of Titi Amayah (2013), who concluded that personal benefits were one of three main motivations that makes a unique contribution to the process of knowledge sharing.

\section{Conclusion}

The aim of this paper was to explore communication of strategic knowledge among top and middle managers in the public sector domain through the application of 'ba'. Our findings reveal that public sector knowledgesharing research is fragmented. The findings of this research also suggest that knowledge sharing, in reference to the strategy communication process in a public sector organization, depends on the social practices of individuals. Furthermore, the process of communication is strongly associated with the tribal affiliations of individuals. The process of knowledge sharing between and within top and middle managers was found to be more active on the collective level than the individual. Moreover, the willingness to share strategy-related knowledge is affected by the prejudices of individuals as well as social connections and stereotypes prevalent among the managerial groups. To this end, we concluded that given appropriate contexts or 'ba', there will be a greater propensity for knowledge sharing within public sector organizations.

\subsection{Recommendations and managerial implications}

If the findings are generalized beyond the single-selected organization, implications for practice could be clear. It is vital to appreciate that human interactions are complicated and require continuous study. Future research could involve conducting a conventional survey to predict some of the influencing communication attributes of top and middle managers in each strategy phase to see if their opinions change in each phase.

The research findings suggest a number of managerial implications and recommendations which can be taken into consideration. First, is the need for public sector organizations to provide necessary spaces for managers to be able to share their knowledge. Having the appropriate collective spaces will invariably facilitate socialization, which fosters organizational knowledge creation. In addition, for public sector organizations to successfully implement their planned strategies, it is imperative for them to promote a collaborative knowledge sharing culture. This may require them to implement and execute social engagement activities that encourage the alignment of individuals of different backgrounds and support the spirit of teamwork and togetherness.

\subsection{Directions for future research}

Since the focus of this study has been on perceptions of top and middle management, there is scope for further research to examine how social spaces impact knowledge sharing among other cadres of the organization (for instance, front-line employees). Furthermore, our focus was on one public sector ministry, but the possibility exists to examine the research findings in a wider context (multiple case studies) for the purpose of generalization of results.

\section{References}

Adamides, E., 2015. Linking operations strategy to the corporate strategy process: A practice perspective. Business Process Management Journal, 21 (2), pp. 267-287.

Ahearne, M., Lam, S. and Kraus, F., 2014. Performance impact of middle managers' adaptive strategy implementation: The role of social capital. Strategic Management Journal, 35 (1), pp. 68-87.

Ahmad, F. and Karim, M. 2019. Impacts of knowledge sharing: a review and directions for future research. Journal of Workplace Learning, 31(3), pp. 207-230. https://doi.org/10.1108/JWL-07-2018-0096

Al Saifi, S., Dillon, S. and McQueen, R., 2016. The relationship between management support and knowledge sharing: An exploratory study of manufacturing firms. Knowledge and Process Management, 23 (2), pp. 124-135.

Andrews, K. and Delahaye, B., 2000. Influences on knowledge processes in organizational learning: the psychological filter. Journal of Management Studies, 37(6), pp. 2322-2380.

Bennett, R., 2001. Ba' as a determinant of salesforce effectiveness: An empirical assessment of the applicability of the Nonaka-Takeuchi model to the management of the selling function. Marketing Intelligence and Planning, 19 (3), pp. 188-99.

Blackler, F., 1995. Knowledge, knowledge work and organizations: An overview and interpretation. Organization Studies 16(6), pp. 1021-1046.

Bourdieu, P., 1990. The logic of practice. Cambridge, UK: Polity Press.

Boyatzis, R.E., 1998. Transforming qualitative information: thematic analysis and code development, Thousand Oaks, CA: Sage. 
Braun, V., Clarke, V., Hayfield, N. and Terry, G., 2019. Thematic analysis. in P> Liamputtong (Ed.), Handbook of research methods in health social sciences, Singapore: Springer,,pp. 843-860.

Bromiley, P. and Rau, D., 2016. Operations management and the resource-based view: Another view. Journal of Operations Management, 41, pp. 95-106.

Chenail, R., 2012. Conducting qualitative data analysis: reading line-by-line, but analyzing by meaningful qualitative units. Qualitative Report, 17(1), pp. 266-269.

Choo, W.C. and de Alvarenga Neto, R.C.D., 2010. Beyond the ba: Managing enabling contexts in knowledge organizations. Journal of Knowledge Management, 14(4), pp. 592-610.

Cooper, B., Wang, J., Bartram, T., and Cooke, F., 2019. Well-being-oriented human resource management practices and employee performance in the Chinese banking sector: the role of social climate and resilience. Human Resource Management, 58(1), pp. 85-97.

Corley, K. and Gioia, D., 2004. Identity ambiguity and change in the wake of a corporate spin-off. Administrative Science Quarterly, 49(2), pp. 173-208.

Dodgson, M., 1993. Organizational learning - A review of some literature. Organization Studies, 14(3), pp. 375-94.

Donate, M. and de Pablo, J., 2015. The role of knowledge-oriented leadership in knowledge management practices and innovation. Journal of Business Research, 68(2), pp. 360-370.

Dong, Y., Bartol, K., Zhang, Z. and Li, C., 2017. Enhancing employee creativity via individual skill development and team knowledge sharing: Influences of dual-focused transformational leadership. Journal of Organizational Behavior, 38(3), pp. 439-458.

Fletcher, J., 2014. Social communities in a knowledge enabling organizational context: Interaction and relational engagement in a community of practice and a micro-community of knowledge. Discourse and Communication, 8(4), pp. 351-369.

Forés, B. and Camisón, C., 2016. Does incremental and radical innovation performance depend on different types of knowledge accumulation capabilities and organizational size? Journal of Business Research, 69(2), pp. 831-848.

Gatenby, M., Rees, C., Truss, C., Alfes, K. and Soane, E., 2015. Managing change, or changing managers? the role of middle managers in UK public service reform. Public Management Review, 17(8), pp. 1124-1145.

Giddens, A., 1984. The constitution of society: outline of the theory of structuration, Cambridge, UK: Polity Press.

Glaser, L., Fourné, S. and Elfring, T., 2015, Achieving strategic renewal: The multi-level influences of top and middle managers' boundary-spanning. Small Business Economics, 45(2), pp. 305-327.

Grbich, C., 2013. Qualitative data analysis: an introduction. 2nd Edition. London: Sage.

Henttonen, K., Kianto, A. and Ritala, P., 2016. Knowledge sharing and individual work performance: An empirical study of a public sector organization. Journal of Knowledge Management, 20(4), pp. 749-768.

Huy, Q., 2001. In praise of middle managers. Harvard Business Review, 79(8), pp. 72-79.

Inkinen, H., Kianto, A. and Vanhala, M., 2015. Knowledge management practices and innovation performance in Finland. Baltic Journal of Management, 10(4), pp. 432-455.

Jamshed, S. and Majeed, N., 2018. The effect of knowledge sharing on team performance through lens of team culture", Arabian Journal of Business and Management Review (Oman chapter), 7(2), pp. 64-80.

Jarzabkowski, P. 2005. Strategy-as-practice: an activity-based approach, London: Sage.

Jarzabkowski, P. and Spee, A., 2009. Strategy as practice: A review and future directions for the field. International Journal of Management Reviews, 11(1), pp. 69-75.

Jarzabkowski, P., Kaplan, S., Seidl, D. and Whittington, R., 2016. On the risk of studying practices in isolation: linking what, who, and how in strategy research. Strategic Organization, 14(3), pp. 248-259.

Jørgensen, R., Edwards, K., Scarso, E. and Ipsen, C., 2020. Improving public sector knowledge sharing through communities of practice. VINE Journal of Information and Knowledge Management Systems, ahead-of-print No. ahead-of-print. https://doi.org/10.1108/VJIKMS-08-2019-0115.

Lahti, R.K. and Beyerlein, M.M. 2000. Knowledge transfer in management consulting: a look at 'the firm'. Business Horizons, 43, p. 65.

Latilla, V.M., Frattini, F., Petruzzelli, A.M. and Berner, M., 2018. Knowledge management, knowledge transfer and organizational performance in the arts and crafts industry: A literature review. Journal of Knowledge Management, 22(6), pp. 1310-1331.

Liu, C., Horng, J., Chou, S., Huang, Y. and Chang, A., 2018. How to create competitive advantage: the moderate role of organizational learning as a link between shared value, dynamic capability, differential strategy, and social capital. Asia Pacific Journal of Tourism Research, 23(8), pp. 747-764.

Low, K.Y.J. and Ho, E.Y.C., 2016. A knowledge-based theory of the multinational economic organization. Long Range Planning, 49(6), pp. 641-647.

Mantere, S., 2008. Role expectations and middle manager strategic agency. Journal of Management Studies, 45(2), pp. 294-316.

Martin-Rios, C., 2016. Innovative management control systems in knowledge work: a middle manager perspective. Journal of Management Control, 27(2-3), pp. 181-204.

Nikolaou, I., 2019. A framework to explicate the relationship between CSER and financial performance: an intellectual capital-based approach and knowledge-based view of firm. Journal of the Knowledge Economy, 10, pp.1427-1446.

Nishida, K., 1990. An inquiry into the good, translated by Abe, M. and Ives, C., New Haven, CT: Yale University. 
Nonaka, I. and Konno, N., 1998. The concept of 'Ba': Building a foundation for knowledge creation. California Management Review, 40(3), pp. 40-54.

Nonaka, I. and Toyama, R., 2015. The knowledge-creating theory revisited: Knowledge creation as a synthesizing process. in J.S. Edwards (Ed.), The essentials of knowledge management, London: Palgrave Macmillan, pp. 95-110.

Nonaka, I. Von Krogh, G. and Voelpel, S., 2006. Organizational knowledge creation theory: Evolutionary paths and future advances. Organization Studies, 27(8), pp. 1179-1208.

Nonaka, I., Toyama, R. and Konno, N., 2001. 'SECI, ba and leadership: a unified model of dynamic knowledge creation', in I. Nonaka and D. Teece (eds) Managing industrial knowledge: creation, transfer and utilization, London: Sage, pp. 1343.

Obembe, D., 2010. Understanding individual action: when employees contravene management directives to foster knowledge sharing. Management Research Review, 33(6), pp. 656-666. DOI: 10.1108/01409171011050235.

Obembe, D., 2013. Knowledge sharing, sustained relationships and the habitus. Management Learning, 44(4), pp. $355-372$.

Obembe, D., Al Mansour, J. and Kolade, O., 2020. Strategy communications and transition dynamics among managers: A public sector organization perspective. Management Decision, Ahead-of-print DOI: 10.1108/MD-11-2019-1589.

Ouakouak, M., Ouedraogo, N. and Mbengue, A., 2014. The mediating role of organizational capabilities in the relationship between middle managers' involvement and firm performance: a European study. European Management Journal, 32(2), pp. 305-318.

Patton, M., 2015. Qualitative research and evaluation methods (4th Ed). London: Sage.

Peters, B., 2019. Institutional theory in political science: the new institutionalism. Cheltenham, UK: Edward Elgar.

Raes, A., Heijltjes, M., Glunk, U. and Roe, R., 2011. The interface of the top management team and middle managers: a process model. Academy of Management Review, 36(1), pp. 102-126.

Rashidirad, M., Salimian, H., Soltani, E. and Fazeli, Z., 2017. Competitive strategy, dynamic capability, and value creation: Some empirical evidence from UK telecommunications firms. Strategic Change, 26(4), pp. 333-342.

Rouleau, L. and Balogun, J., 2011. Middle managers, strategic sensemaking, and discursive competence. Journal of Management Studies, 48(5), pp. 953-983.

Saeed, H. and Sattar Chaudhry, A., 2002. Using Dewey Decimal classification scheme (DDC) for building taxonomies for knowledge organization. Journal of Documentation, 58(5), pp. 575-583.

Shimizu, H., 1995., Ba-principle: New logic for the real-time emergence of information. Holonics, 5(1), pp. 67-79.

Simmel, G., 1997. Spatial and urban culture. In: D.P. Frisby and M. Featherstone (Eds.), Simmel on culture: selected writings, London: Sage, , pp. 137-186.

Taylor, W.A. and Wright, G.H., 2004. Organizational readiness for successful knowledge sharing: Challenges for public sector managers. Information Resources Management Journal (IRMJ), 17(2), pp. 22-37.

Titi Amayah, A., 2013. Determinants of knowledge sharing in a public sector organization. Journal of Knowledge Management, 17(3), pp. 454-471.

Tolbert, P.S. and Zucker, L.G., 1999. The institutionalization of institutional theory. In: S. Clegg, C. Hardy and W. Nord (Eds.), Handbook of organization studies, London: Sage, pp. 175-190.

Tsoukas, H., 2005. Complex knowledge: studies in organizational epistemology, Oxford, UK: Oxford University Press.,.

Von Krogh, G., 1998. Care in knowledge creation. California Management Review, 40(3), pp. 133-153.

Von Krogh, G., Ichijo, K. and Nonaka, I., 2000. Enabling knowledge creation: how to unlock the mystery of tacit knowledge and release the power of innovation, Oxford, UK: Oxford University Press.

Von Krogh, G., Nonaka, I. and Ichijo, K., 1997. Develop knowledge activists! European Management Journal, 15(5), pp. 475483.

Von Krogh, G., Nonaka, I. and Rechsteiner, L., 2012. Leadership in organizational knowledge creation: A review and framework. Journal of Management Studies, 49(1), pp. 240-277.

Wang, S. and Noe, R., 2010. Knowledge sharing: a review and directions for future research. Human Resource Management Review, 20(2), pp. 115-131.

Whittington, R., 2006. Completing the practice turn in strategy research. Organization Studies, 27(5), pp. 613-634.

Wiig, K., 1997. Knowledge management: where did it come from and where will it go? Expert Systems with Applications, 13(1), pp. 1-14.

Wooldridge, B. and Floyd, S., 1990. The strategy process, middle management involvement, and organizational performance. Strategic Management Journal, 11(3), pp. 231-241.

Wooldridge, B., Schmid, T., and Floyd, S., 2008. The middle manager perspective on strategy process: Contributions, synthesis, and future research. Journal of Management, 34(6), pp. 1190-1221.

Yin, R., 2014. Case study research: design and methods. 5th Edition. Thousand Oaks, CA: Sage,

Yli-Renko, H., Autio, E. and Sapienza, H., 2001. Social capital, knowledge acquisition, and knowledge exploitation in young technology-based firms. Strategic Management Journal, 22(6-7), pp. 587-613. 